Огляди літератури, оригінальні дослідження, погляд на проблему

УДК 616.37-002.2-06:616.12-005.4]-02:616-056.5

DOI 10.11603/1811-2471.2018.v0.i1.8572

\title{
ДИСБАЛАНС КАЛІКРЁ̈Н-КІНІНОВОЇ СИСТЕМИ У ХВОРИХ НА ХРОНІЧНИЙ ПАНКРЕАТИТ У ПОЄДНАННІ ЗІ СТАБІЛЬНОЮ ІШЕМІЧНОЮ ХВОРОБОЮ СЕРЦЯ
}

\author{
○Л. С. Бабінець, Н. А. Мельник, У. М. Захарчук, Г. В. Адамів, В. Є. Шамбель \\ ДВНЗ «Тернопільський державний медичний університет імені І. Я. Горбачевського МОз України»
}

PЕзюмЕ. Калікреїн-кінінова система є однією з центральних систем, що беруть участь у процесах згортання крові й фібринолізу, імунних реакціях, розвитку запалення та формуванні больового синдрому в пацієнтів із поєднаним перебігом хронічного панкреатиту та стабільної ішемічної хвороби серця.

КлючовІ СлОВА: калікреїн-кінінова система; хронічний панкреатит; стабільна ішемічна хвороба серця.

Вступ. Універсальність калікреїн-кінінової системи (ККС) обумовлена ї̈ тісним зв'язком із чотирма найважливішими гуморальними протеолітичними системами: згортання, фібринолітичною, ренін-ангіотензиновою і системою комплементу $[1,2]$. Також відомо, що стан показників ККС відображає активність запальної реакції в організмі, стан мікроциркуляції, тяжкість перебігу захворювання. ККС належить значна роль у виникненні та прогресуванні як хронічного панкреатиту (ХП), так і стабільної ішемічної хвороби серця (CIXC). Вона $\epsilon$ однією з центральних систем, що беруть участь у процесах згортання крові й фібринолізу, імунних реакціях, розвитку запалення та формуванні больового синдрому в пацієнтів із поєднаним перебігом ХП та СІXC $[4,5]$.

Мета - дослідити особливості змін ККС у хворих на ХП в залежності від наявності СІХC.

Матеріал і методи дослідження. Всіх обстежених пацієнтів було поділено на дві групи: 1 група (30 пацієнтів) - хворі на ХП; 2 група (32 пацієнти) хворі на ХП в поєднанні із СІХС (стенокардія напруги I-ІІ функціональних класів). Про стан ККС судили за наступними показниками: протеолітична активність плазми (ПРА) - визначали за гідролізом протамінсульфату, калікреїн (КК) - визначали за допомогою хромозиму PK, $a_{1}$-інгібітор протеїназ $\left(a_{1}-\right.$-ІП) та $a_{2}$-макроглобулін $\left(a_{2}-M Г\right)$ - визначали за методом К. М. Веремєєнко, кініназа-ІІ визначали за методом Folk et al. [3].

Результати й обговорення. Встановлено статистично значимо вищий рівень ПРА у хворих на ХП у поєднанні із СІХC, порівняно з групою хворих на ХП, що вказує на активацію загального протеолізу. Також аналіз показників ККС у хворих на ХП із СІХС засвідчив активацію специфічного протеолізу, або кініногенезу, за статистично значимо вищим рівнем протеолітичного ферменту КК стосовно групи ХП. Прослідковувалось зниження рівня ПКК у хворих групи ХП+СІХС відносно групи ХП на 20,95\%.

Рівень $a_{1}-І$ у у хворих із наявністю СІХC, як ферменту, що здійснює контроль над активністю протеолізу завдяки зв'язуванню протеолітичних ферментів екзо-та ендогенного походження, був статистично значимо вищий, ніж у групі хворих на ХП, на 13,79 \%. Також у хворих із наявністю СІХС було виявлено статистично значиме зниження

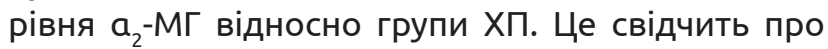
виснаження інгібіторного захисту організму.

Рівень активності кінінази-ІІ у хворих із наявністю СІХС був статистично значимо нижчим, ніж у хворих на ХП, на 14,98 \%, що свідчить про осла6лення захисних реакцій організму через надмірний кініногенез.

Висновки. У хворих групи ХП+СІХС встановлено більш виражену активацію системи загального (за статистично значимо вищими показниками ПРА та а цифічного протеолізу (за статистично значимо вищими показниками ПКК, КК та $\mathrm{a}_{1}$-ІП стосовно хворих групи ХП). Це свідчить про більшу активізацію процесів катаболізму-запалення у хворих на ХП із наявністю CIXC.

\section{ЛІТЕРАТУРА}

1. Архій Е. Й. Хронічний панкреатит, поєднаний з ішемічною хворобою серця: особливості процесів травлення та інтерлейкінового статусу / Е.Й. Архій, О.М. Москаль, Т.В. Мишанич // Науковий вісник Ужгородського університету. Сер.: Медицина. - 2014. - Вип. 1. - С. 24-27.

2. Бабінець Л. С. Стан показників калікреїн-кінінової системи хворих на хронічний біліарний панкреатит

із супутнім ожирінням / Л. С. Бабінець, К. Ю. Кицай, О. І. Криськів // Здобутки клінічної і експериментальної медицини. - 2016. - № 2. - С. 105.

3. Веремеенко К. Н. Протеолитические ферменты и их ингибиторы. Новые области применения в клинике / К. Н. Веремеенко // Врачебное дело. - 1994. - № 31. C. 8-13. 
Огляди літератури, оригінальні дослідження, погляд на проблему

4. Губергриц Н. Б. Метаболическая панкреатология / Н. Б. Губергриц, А. Н. Казюлин. - Донецк : Лебедь, 2015. - С. 464-471.

5. Кондратьева Е. И. Активность калликреин-кининовой системы у детей в норме и при отдельных па-

тологических состояниях / Е. И. Кондратьева, Т. Е. Тропова, С. А. Суханова [и др.] // Бюллетень сибирской медицины. - 2014. - № 4 (2). - С. 36-41.

\section{REFERENCES}

1. Arkhii, E.Y., Moskal, O.M., \& Myshanych, T.V. (2014). Khronichnyi pankreatyt, poiednanyi z ishemichnoiu khvoroboiu sertsia: osoblyvosti protsesiv travlennia ta interleikinovoho statusu [Chronic pancreatitis combined with ischemic heart disease: features of digestive processes and interleukin status]. Naukovyi visnyk Uzhhorodskoho universytetu. Seriia Medytsyna - Scientific Bulletin of Uzhhorod University. Series Medicine, 1, 24-27 [in Ukrainian].

2. Babinets, L.S., Kitsai, K.Yu., \& Kryskiv, O.I. (2016). Stan pokaznykiv kalikrein-kininovoi systemy khvorykh na khronichnyi biliarnyi pankreatyt iz suputnim ozhyrinniam [State of indicators of the kallikrein-kinin system of patients with chronic biliary pancreatitis with concomitant obesity]. Zdobutkyklinichnoi i eksperymentalnoi medytsyny-Achievements of Clinical and Experimental Medicine, 2, 105 [in Ukrainian].
3. Veremeyenko, K.N. (1994). Proteoliticheskie fermenty i ikh ingibitory. Novye oblasti primeneniya v klinike [Proteolytic enzymes and their inhibitors. New areas of application in the clinic]. Vrachebnoe delo-Medical Business, 31, 8-13 [in Russian].

4. Gubergits, N.B., \& Kazyulin, A.N. (2015). Metabolicheskaya pankreastologiya [Metabolic pancreatology]. Donetsk: Swan [in Russian].

5. Kondratyev, E.I., Tropova, T.E., \& Sukhanova, S.A. (2014). Aktivnost kallikrein-kininovoy sistemy u detei v norme i pri otdalenykh patologicheskikh sostoyaniyakh [The activity of the kallikrein-kinin system in children is normal and in certain pathological conditions]. Buyleten sibirskoy meditsiny - Journal of Siberian Medicine, 4 (2), 3641 [in Russian].

\title{
ДИСБАЛАНС КАЛЛИКРЕИН-КИНИНОВОЙ СИСТЕМЫ У БОЛЬНЫХ ХРОНИЧЕСКИМ ПАНКРЕАТИТОМ В СОЧЕТАНИИ СО СТАБИЛЬНОЙ ИШЕМИЧЕСКОЙ БОЛЕЗНЬЮ СЕРДЦА
}

๑Л. С. Бабинец, Н. А. Мельник, У. М. Захарчук, Г. В. Адамов, В. Е. Шамбель

ДВНЗ «Тернопольский государственный медицинский университет имени И. Я. Горбачевского МОЗ Украчны»

РЕЗЮМЕ. Калликреин-кининовая система является одной из центральных систем, участвующих в процессах свертывания крови и фибринолиза, иммунных реакциях, развитии воспаления и формировании болевого синдрома у пациентов с сочетанным течением хронического панкреатита и стабильной ишемической болезни сердца.

КЛЮчЕВЫЕ СЛОВА: калликреин-кининовая система; хронический панкреатит; стабильная ишемическая болезнь сердца.

\section{DISBALANCE OF THE KALLIKREIN-KININ SYSTEM IN PATIENTS WITH CHRONIC PANCREATITIS IN CONNECTION WITH STABLE ISCHEMIC HEART DISEASE}

\author{
@L. S. Babinets, N. A. Melnyk, U. M. Zakharchuk, G. V. Adamiv, V. Ye. Shambel \\ I. Horbachevsky Ternopil State Medical University
}

SUMMARY. The kallikrein-kinin system is one of the central systems involved in blood coagulation and fibrinolysis, immune responses, inflammation and pain forming in patients with a combined course of chronic pancreatitis and stable coronary heart disease.

KEY WORDS: kallikrein-kinin system; chronic pancreatitis; stable coronary artery disease. 